\title{
Pengaruh Pemberian Pasta Jahe (Zingiber Officinale Rosceae) Terhadap Kualitas Daging Ayam Kampung
}

\author{
Arni ${ }^{1}$, Harapin Hafid ${ }^{2}$ dan Rahim Aka ${ }^{2}$ \\ ${ }^{1}$ Alumnus Jurusan Peternakan Fakultas Peternakan UHO \\ ${ }^{2}$ Dosen Jurusan Peternakan Fakultas Peternakan UHO \\ Email : rahim.aka05@gmail.com
}

\begin{abstract}
ABSTRAK
Penelitian ini bertujuan untuk mengetahui pengaruh tingkat pemberian pasta jahe terhadap kualitas fisik daging ayam kampung, mengetahui pengaruh tingkat pemberian pasta jahe terhadap kualitas kimia daging ayam kampung dan kualitas organoleptik daging ayam kampung dan rimpang jahe gajah. Penelitian ini menggunakan 4 ekor ayam kampung yang berumur 3 tahun dengan berat $2 \mathrm{~kg}$. Penelitian ini terdiri atas 3 perlakuan (P0 : tingkat pemberian $0 \%, \mathrm{P} 1$ : tingkat pemberian $25 \%$ dan $\mathrm{P} 2$ : tingkat pemberian 50\%. Data yang diperoleh dianalisis menggunakan rancangan Acak Lengkap dengan 3 perlakuan dan tiga ulangan dengan konsentrasi 0\%, 25\% dan 50\%. Variable yang diamati adalah susut masak, kadar air, kadar protein, kadar lemak dan organoleptik. Data yang diperoleh dianalisa dengan menggunakan analisis sidik ragam dan jika ada perbedaan pengaruh diantara perlakuan maka dilanjutkan dengan uji Beda Nyata Jujur (BNJ). Hasil penelitian menunjukkan bahwa penambahan pasta jahe 25\% dan 50\% pada daging ayam kampung berpengaruh signifikan terhadap penurunan presentase susut masak, berpengaruh nyata terhadap peningkatan kadar protein dan $\mathrm{pH}$ pada daging ayam kampung dan menurunkan kadar lemak daging ayam kampung. Perlakuan terbaik adalah pemberian pasta jahe sebanyak 50\%. Disimpulkan bahwa pembaluran pasta jahe pada daging ayam kampung pada konsentrasi $50 \%$ memberikan pengaruh yang baik pada kualitas fisik yaitu susut masak $(3,02 \pm 0,02) \%$ dan $\mathrm{pH}$ $(6,50 \pm 0,05) \%$ dan kualitas kimia ditinjau dari kadar protein $(23,63 \pm 0,16) \%$, kadar lemak $(12,65 \pm 0,39) \%$.
\end{abstract}

Kata kunci : pasta jahe, kualitas fisik dan kimia, kualitas organoleptik, daging ayam kampung

\begin{abstract}
This study was to determine the effect of addition of ginger pasta to the physical quality of chicken meat, determine the effect of administration of ginger paste to the chemical quality, chemical quality and organoleptic quality of chicken meat. This study were used four chickens were 3rd years old with weight $2 \mathrm{~kg}$. this study consisted of three treatments (P0: 0\%, P1: $25 \%$ and P2: $50 \%$ ginger pasta. The data were analyzed using a completely randomized design with three treatments and three replications. Variable observed were cooking loss, dry mater, crude protein, crude fat and organoleptic. Data were analyzed using analysis of variance and if three is a difference between the effect of treatment the continued with test Honestly significant difference (HSD). The results showed that 25\% and 50\% addition of ginger paste in chicken meat significantly decrease the percentage of cooking loss, significantly effected the increasing protein content and $\mathrm{pH}$ on chicken meat and lower the fat content of chicken meat. The best treatment is the addition of ginger paste was $50 \%$. It is concluded that $50 \%$ ginger pasta in chicken meat give a good influence on the physical quality that cooking loss $(3.02 \pm 0.02) \%$ and $\mathrm{pH}(6.50) \%$ and protein $(23.63 \pm 0.16) \%$, fat content $(12.65 \pm 0.39) \%$.
\end{abstract}

Key words: ginger pasta, physical quality, quality chemical, organoleptic quality, meat chicken. 


\section{PENDAHULUAN}

\section{A. Latar Belakang}

Ayam kampung sebagai salah satu sumber plasma nutfah hewani yang layak untuk dikembangkan. Unggas ini mempunyai prospek yang menjanjikan, secara ekonomi karena merupakan bahan pangan bergizi tinggi serta permintaannya cukup tinggi.

Daging merupakan suatu bahan pangan asal hewani yang mempunyai kandungan gizi tinggi, yang dibutuhkan oleh tubuh untuk mempertahankan fungsi fisiologisnya. Daging mengandung asamasam amino esensial yang lengkap dan seimbang serta lebih mudah dicerna dibandingkan protein yang berasal dari nabati. Daging bersifat mudah rusak (perishable) akibat proses mikrobiologis, kimia dan fisik bila tidak ditangani dengan baik akan berdampak pada menurunnya kualitas serta daya simpan daging (Hafid, 2013).

Daging ayam kampung merupakan salah satu jenis daging yang cukup populer dimasyarakat Indonesia karena rasanya yang lebih enak dan rendah kandungan lemak dan kolesterolnya sehingga banyak dikonsumsi oleh masyarakat dari tingkat atas sampai tingkat bawah. Salah satu kelemahan dari ayam kampung adalah dibutuhkan waktu yang lebih lama untuk dipotong. Daging ayam kampung umur 2 sampai tiga tahun sudah menjadi alot sehingga diperlukan bahan pengempuk alami untuk meningkatkan kualitas daging ayam kampung.

Aspek kualitas merupakan hal yang paling penting diperhatikan dalam pemilihan suatu bahan pangan. Upaya mempertahankan kualitas daging dilakukan dengan mencegah kerja enzim endogen dan kontaminasi mikroba yang secara alami akan merusak daging. Penggunaan tumbuhan herbal pada penanganan daging untuk mempertahankan kualitasnya sebenarnya telah lama dilakukan diantaranya penggunaan getah pepaya, nanas dan lengkuas. Sebagai salah satu bahan alami, jahe memiliki kemampuan sebagai agen pengempuk dan dan anti mikroba pada daging (Komariah, dkk 2004).

Seiring dengan berkembangnya pemakaian bahan-bahan alami untuk pengobatan, diikuti pula dengan penggunaan bahan alami pada proses penanganan daging salah satunya pemanfaatan tanaman jahe yang penggunaannya aman, bebas residu, ekonomis dan lebih efisien. Adanya peningkatan kebutuhan masyarakat terhadap jahe, maka perlu dibuat penganekaragaman produk olahannya.

Jahe menurut (Anonimous ${ }^{\mathrm{a}}$, 2011) merupakan salah satu sumber enzim protease yang disebut zingibain, yang kemampuan proteolitiknya mampu menghidrolisis ikatan peptida daging dan enzim lipase yang mampu memecah lemak. Jahe memiliki zat aktif yang terdapat pada minyak volatil (volatile oil) yang mempunyai komposisi antara 1-3\% dari bobot. Zat aktif tersebut dapat berfungsi sebagai antioksidan alami (natural antioxidant) yang dapat menurunkan tingkat oksidasi dan mencegah bau (off-flavor). Selain itu jahe mempunyai komposisi minyak atsiri dan senyawa antioksidan seperti gingerol, shogaol, zingeron dan diarilheptanoid.

Sehubungan dengan uraian diatas telah dilakukan penelitian tentang pengaruh pemberian pasta jahe terhadap kualitas daging ayam kampung.

\section{MATERI DAN METODE}

\section{A. Lokasi dan Waktu Penelitian}

Penelitian ini dilaksanakan di Laboratorium Tekhnologi Pangan Fakultas Pertanian Universitas Halu Oleo, Kendari, pada bulan April 2014. 


\section{B. Bahan dan Alat}

Bahan yang digunakan dalam penelitian ini menggunakan sampel daging paha ayam kampung (drumstick) dan rimpang jahe putih yang segar atau dikenal dengan jahe gajah (Zingiber officinale Roxc.).

Adapun alat yang digunakan untuk penyiapan sampel antara lain kulkas, timbangan digital, blender, plastik polietilena, pisau, garpu, pemanas listrik (hot plate), nampan, piring, penangas air dan tisue. Alat-alat yang digunakan uji fisik, yaitu pH meter (Hanna Instrument). Alatalat yang digunakan untuk analisis kimia, yaitu peralatan gelas (labu Kjeldahl, labu Soxhlet, kertas saring, pipet tetes, pipet volumetrik, gelas ukur, tabung reaksi, gelas piala, labu takar), oven, tanur listrik, desikator, timbangan analitik, cawan, penjepit, Texture Analyzer, pengepres hidraulik, tabung reaksi, pipet mohr, inkubator dan Bunsen.

\section{Prosedur Penelitian}

Pertama-tama disediakan ayam kampung jantan sebanyak 4 ekor berumur sekitar 3 tahun dengan berat $2 \mathrm{~kg}$ dan rimpang jahe gajah (jahe putih). Ayam tersebut dipotong secara halal, di cabuti bulunya dan diambil bagian pahanya diiris mengikuti arah serabut otot dan dibagi sama dengan berat perlakuan 100 gram daging, rimpang jahe 20 gram yang telah dibersihkan, dicacah dan ditambahkan air 5 ml kemudian diblender/dihaluskan sehingga menjadi pasta jahe. Selanjutnya daging ditusuk-tusuk menggunakan garpu dengan tujuan agar pasta jahe tersebut dapat meresap kedalam daging dan perendaman daging ayam 100 gram dalam pasta jahe sesuai perlakuan tingkat pemberian $0 \%$ sebagai kontrol, tingkat pemberian $25 \%$ dan tingkat pemberian $50 \%$.

Setelah itu daging disimpan pada suhu dingin $\left(4^{0} \mathrm{C}\right)$ selama 24 jam setelah itu pasta yang ada pada permukaan sampel daging dibersihkan menggunakan tissue, selanjutnya dilakukan uji fisik dan kimia. Setelah itu daging dimasak untuk dilakukan uji organoleptik dengan menggunakan panelis 15 orang.

\section{Rancangan Penelitian}

Penelitian ini dilakukan dengan menggunakan metode eksperimental yaitu dengan memberikan perlakuan berupa pembaluran daging ayam pada pasta Jahe (Zingiber officinale Rosceae). Rancangan yang digunakan adalah rancangan acak lengkap (RAL) dengan 3 perlakuan dan 3 ulangan sesuai dengan petunjuk Steel dan Torrie.

Perlakuan yang diberikan adalah pembaluran daging pada pasta jahe (Zingiber officinale Rosceae) dengan 3 perlakuan, yaitu:

$\mathrm{P}_{0}=$ Tingkat pemberian 0 gram;

$\mathrm{P}_{1}=$ Tingkat pemberian 25 gram; dan

$\mathrm{P}_{2}=$ Tingkat pemberian 50 gram.

Model matematika dari rancangan percobaan mengikuti model matematika Steel dan Torrie (1993), sebagai berikut:

$\mathrm{Yij}=+\tau \mathrm{i}+\varepsilon \mathrm{ij} \ldots \ldots \ldots \ldots \ldots \ldots \ldots(1)$
$\mathrm{i}=1,2,3 \quad \mathrm{j}=1,2,3$

Yij : Nilai pengamatan satuan percobaan kej pada perlakuan ke-i.

: Nilai rata-rata sesunguhnya.

тi : Pengaruh perlakuan taraf pemberian pasta jahe

عij : Pengaruh galat percobaan akibat perlakuan ke-i pada percobaan ke-j

\section{E. Variabel Penelitian}

A. Sifat Fisik Daging

\section{1) Susut Masak (Cooking Loss)}

Pengukuran susut masak berdasarkan Soeparno (2009) dilakukan pada sampel daging yang mengalami pemasakan pada suhu $80^{\circ} \mathrm{C}$ selama 60 menit, kemudian 
didinginkan pada temperatur kamar dan selanjutnya didinginkan pada temperatur rendah $\pm 0^{\circ} \mathrm{C}$. Setelah itu sampel daging di lap dengan kertas tissue untuk menyerap air pada permukaan daging, selanjutnya sampel ditimbang. Nilai susut masak (Cooking Loss) daging dihitung dengan rumus sebagai berikut :

Susut masak $(\%)=$

$\frac{\text { berat sblm dimasak-berat stlh dimasak }}{\text { berat sblm dimasak }}$

\section{2) $\mathbf{p H}$}

Pengujian $\mathrm{pH}$ daging dilakukan dengan menggunakan metode Bouton et al. (1971) dalam Soeparno (2009) yaitu sampel daging seberat $10 \mathrm{~g}$ dihaluskan kemudian dicampur dengan $10 \mathrm{ml}$ aquadest kemudian diaduk hingga homogen. $\mathrm{pH}$ meter dibersihkan dengan aquadest dan dimasukkan buffer $\mathrm{pH} 7$ untuk disesuaikan pH-nya. Setiap larutan diukur pH-nya sebanyak tiga kali dan hasilnya direrata sebagai nilai $\mathrm{pH}$ daging.

\section{B. Sifat Kimia Daging}

1) Kadar Air (KA) (AOAC, 1984)

Mula-mula cawan kosong dikeringkan di dalam oven pada suhu $105^{\circ} \mathrm{C}$ selama 15 menit dan didinginkan di dalam desikator, kemudian ditimbang. Sebanyak 5 gr sampel dimasukkan dalam cawan yang telah ditimbang dan selanjutnya dikeringkan dalam oven bersuhu $105^{\circ} \mathrm{C}$ selama 6 jam. Cawan yang berisi sampel yang telah dikeringkan selanjutnya dipindahkan ke dalam desikator, didinginkan kemudian ditimbang. Pengeringan dilakukan sampai diperoleh berat konstan.

berikut:

Persentase kadar air dihitung sebagai

\footnotetext{
Kadar air $(\%)=$

(Berat awal sampel-Berat akhir sampel) $(g)$

Berat awal sampel $(g)$

x 100\% ....(3)
}

\section{2) Kadar Protein (AOAC, 1984)}

Pengukuran kadar protein dilakukan dengan menggunakan metode mikroKjeldahl dengan cara kerja yaitu, sampel yang digunakan sebanyak 0,2 gr dimasukkan ke dalam labu Kjeldahl $100 \mathrm{ml}$, lalu ditambahkan 2 gr $\mathrm{K}_{2} \mathrm{SO}_{4}, 40 \mathrm{mg} \mathrm{HgO}$ dan 2,5 $\mathrm{ml} \mathrm{H}_{2} \mathrm{SO}_{4}$. Selama 30 menit dilakukan destruksi sampai diperoleh cairan hijau jernih. Didestilasi setelah dingin ditambahkan air destilat sebanyak $35 \mathrm{ml}$ dan $\mathrm{NaOH}$ pekat sebanyak $10 \mathrm{ml}$ sampai berwarna coklat kehitaman lalu ditampung ke dalam Erlenmeyer $125 \mathrm{ml}$ yang berisi 5 ml $\mathrm{H}_{3} \mathrm{PO}_{3}$, kemudian dititrasi dengan $\mathrm{HCl}$ $0,02 \mathrm{ml}$ menggunakan indikator. Untuk larutan blanko dilakukan dengan cara yang sama tetapi tanpa menggunakan sampel. Kadar nitrogen dihitung dengan rumus :

Nitrogen $(\%)=\frac{(\text { HCl-blanko }) \times N \text { HCl } \times 14.007}{m g \text { sampel }}$ x $100 \% \ldots \ldots \ldots \ldots \ldots \ldots \ldots . \ldots \ldots$ (4)

Selanjutnya persentase kadar protein dihitung sebagai berikut:

Kadar protein (\%)

$=6,25 \times \%$ Nitrogen

\section{3) Kadar Lemak (AOAC, 1984 )}

Sampel sebanyak 5 gr dimasukkan ke dalam selongsong pengesktrak, kemudian dimasukkan ke dalam labu soxhlet dan diekstraksi dengan menggunakan petroleum eter selama 6 jam. Minyak atau lemak yang tertampung dalam labu. Kemudian labu tersebut dipanaskan di dalam oven $105^{\circ} \mathrm{C}$ selama

1 jam dan ditimbang.

Persentase kadar lemak dihitung sebagai berikut:

Kadar lemak $(\%)=$

Berat labu akhir-Berat labu awal $(g)$

Berat sampel $(g)$

x $100 \%$ (6) 


\section{c) Uji Organoleptik}

Uji organoleptik merupakan pengujian suatu bahan atau produk berdasarkan kesukaan (Hedonict Test) (Hafid, 2009). Pengujian panelis menggunakan respon suka atau tidak suka terhadap sifat produk hasil eksperimen yang diuji yaitu pembaluran pasta jahe pada daging ayam kampung, dengan jumlah panelis 15 orang mahasiswa Fakultas Peternakan yang termasuk dalam kategori panelis tidak terlatih. Skala hedonik untuk uji organoleptik meliputi rasa, aroma, warna, tekstur,dan keempukan

\section{F. Analisis Data}

Data yang diperoleh dianalisis sidik ragam. Apabila hasil yang diperoleh berpengaruh nyata maka akan dilakukan uji lanjut dengan menggunakan uji BNJ (Beda Nyata Jujur) (Hanafiah, 2011).

\section{HASIL DAN PEMBAHASAN}

\section{A. Kualitas Fisik Daging \\ 1. Susut Masak}

Rataan nilai susut masak daging ayam kampung yang diberi pasta jahe dapat dilihat pada Tabel 3.

Tabel 3. Rata-rata nilai susut masak daging ayam kampung yang diberi pasta jahe

\begin{tabular}{|c|c|c|c|}
\hline \multirow{2}{*}{ Ulangan } & \multicolumn{3}{|c|}{ Perlakuan Pasta Jahe } \\
\hline & P0 $(0 \%)$ & P1 (25\%) & P2 $(50 \%)$ \\
\hline & .................... & & ... \\
\hline 1 & 3,79 & 3,31 & 3,04 \\
\hline 2 & 3,73 & 3,33 & 3,00 \\
\hline 3 & 4,14 & 3,34 & 3,01 \\
\hline Rata-rata & $3,89 \pm 0,22^{\mathrm{a}}$ & $3,33 \pm 0,02^{b}$ & $3,02 \pm 0,02^{\mathrm{c}}$ \\
\hline
\end{tabular}

Ket: Superskrip yang berbeda menunjukkan perbedaan sangat nyata $(p>0,01)$

Analisis sidik ragam menunjukkan bahwa pemberian pasta jahe pada daging ayam kampung berpengaruh sangat nyata $(p>0,01)$ terhadap nilai susut masak daging ayam kampung. Perbedaan nilai susut masak daging ayam kampung ini menunjukkan bahwa tingkat pemberian pasta jahe yang tinggi dapat menurunkan nilai susut masak daging ayam kampung, hal ini disebabkan karena adanya perlakuan penyimpanan pada suhu rendah daging yang direndam dalam pasta jahe juga mempengaruhi status kontraksi myofibril akibat aktivitas enzim protease yang dimiliki oleh rimpang jahe, yang dapat menghidrolisis ikatan peptida protein daging menjadi peptida-peptida yang sederhana dan efektif beraktivitas pada suhu rendah. Hidrolisis ikatan ini akan menyebabkan struktur daging menjadi lebih longgar/renggang sehingga air dalam daging lebih banyak.

Hasil uji lanjut (BNJ) bahwa tingkat pemberian pasta jahe $25 \%$ dengan pemberian $50 \%$ menunujukkan tidak berbeda nyata pada taraf $5 \%$ terhadap nilai susut masak daging ayam kampung. Hal ini menunjukkan selisih tingkat pemberian pasta jahe sebanyak 25\% tersebut aktivitas senyawa yang terdapat dalam pasta jahe relatif masih sama. Pembaluran pasta jahe dapat meningkatkan kualitas daging karena susut masak daging semakin rendah. Semakin rendah susut masak daging, maka kualitasnya semakin baik. Soeparno (2009) mengatakan bahwa daging dengan susut masak yang lebih rendah mempunyai kualitas yang relatif lebih baik daripada daging dengan susut masak yang lebih besar, karena kehilangan nutrisi selama 
pemasakan akan lebih sedikit. Besarnya susut masak dapat dipergunakan untuk mengestimasi banyaknya air yang terikat didalam dan diantara serabut otot. Sejalan dengan pernyataan tersebut maka perlakuan tingkat pemberian pasta jahe dapat meningkatkan kualitas daging ayam kampung.

\section{2. pH Daging}

Pengaruh penambahan pasta jahe terhadap $\mathrm{pH}$ daging ayam kampung dapat dilihat pada Tabel 4.

Tabel 4. Rata-rata nilai $\mathrm{pH}$ daging ayam kampung yang diberi pasta jahe

\begin{tabular}{cccc}
\hline \multirow{2}{*}{ Ulangan } & \multicolumn{3}{c}{ Perlakuan Pasta Jahe } \\
\cline { 2 - 4 } & $\mathrm{P} 0(0 \%)$ & $\mathrm{P} 1(25 \%)$ & $\mathrm{P} 2(50)$ \\
\hline 1 & 6,85 & 6,60 & 6,54 \\
2 & 6,87 & 6,65 & 6,51 \\
3 & 6,85 & 6,62 & 6,45 \\
\hline Rata-rata & $6,86 \pm 0,01^{\mathrm{a}}$ & $6,62 \pm 0,03^{\mathrm{b}}$ & $6,50 \pm 0,05^{\mathrm{c}}$ \\
\hline
\end{tabular}

Ket: Superskrip yang berbeda menunjukkan berbeda sangat nyata $(p>0,01)$

Analisis sidik ragam menunjukkan bahwa penambahan pasta jahe pada daging ayam kampung berpengaruh sangat nyata $(p>0,01)$ terhadap nilai $\mathrm{pH}$ daging ayam kampung. Hasil analisis ragam yang disajikan pada Tabel 1 menunjukkan bahwa pembaluran jahe gajah pada daging paha ayam kampung dengan tingkat pemberian berbeda memberikan perbedaan pengaruh $(\mathrm{P}>0,05)$ terhadap $\mathrm{pH}$ daging ayam kampung, karena ada kecenderungan $\mathrm{pH}$ daging paha ayam kampung menurun seiring dengan peningkatan konsentrasi jahe gajah yang digunakan. Hasil rataan menunjukkan $\mathrm{pH}$ terendah terdapat pada tingkat pemberian pasta jahe $50 \%$ sebesar $6,50 \pm 0,05$ dan tertinggi pada daging tanpa pembaluran pasta jahe, yaitu sebesar $6,86 \pm 0,01$ Penurunan $\mathrm{pH}$ daging paha ayam kampung ini dikarenakan jahe memiliki nilai $\mathrm{pH}$ asam, yaitu 5,4 $-5,8$ sehingga mempengaruhi nilai $\mathrm{pH}$ dan mengakibatkan turunnya $\mathrm{pH}$ daging. Nilai $\mathrm{pH}$ yang dihasilkan sesuai dengan penelitianpenelitian sebelumnya yang telah dilakukan. Hal ini sejalan dengan pernyataan Soeparno (2009) bahwa pH pada produk daging akan semakin menurun sampai tercapai $\mathrm{pH}$ akhir yaitu antara 5,4-5,8.
Hasil penelitian ini mengindikasikan bahwa senyawa yang terdapat dalam jahe dapat mempengaruhi laju glikolisis sehingga turut mempengaruhi $\mathrm{pH}$ daging.

Hal ini sesuai Soeparno (2009) bahwa laju glikolisis postmortem dan secara enzimatis akan menghasilkan asam laktat yang mengakibatkan penurunan $\mathrm{pH}$ daging. Hal ini terlihat pada perlakuan P1 dan P2 terus mengalami penurunan $\mathrm{pH}$ walaupun disimpan pada suhu rendah. Sebagaimana Pearson (1987) mengatakan bahwa suhu yang rendah dapat menghambat penurunan $\mathrm{pH}$ pada daging.

Hasil uji lanjut BNJ antara perlakuan P0, P1 dan P2 menunjukkan berbeda sangat nyata $\quad(p<0,01)$ Kondisi ini mengindikasikan bahwa semakin banyak penambahan pasta jahe pada daging ayam kampung dapat menurunkan $\mathrm{pH}$ daging. Hal ini disebabkan karena enzim mampu bekerja secara maksimal. Sesuai dengan pendapat Wurhayati (2004) menyatakan bahwa pada temperatur rendah, reaksi enzimatis berlangsung lambat, kenaikan temperatur melewati temperatur akan mempercepat reaksi hingga suhu optimum tercapai dan reaksi enzimatis mencapai maksimum. Kenaikan temperatur melewati temperatur optimum akan menyebabkan enzim 
terdenaturasi/rusak dan menurunkan kecepatan reaksi enzimatis. Enzim bekerja optimal pada suhu $30^{\circ} \mathrm{C}$ atau pada suhu tubuh dan akan rusak. Jika suhunya kembali normal enzim mampu bekerja kembali. Sementara pada suhu tinggi, enzim rusak dan tidak dapat berfungsi kembali. (Sumartha, 1990). Suhu optimum aktivitas enzim papain berkisar antara $50^{\circ} \mathrm{C}-65^{\circ} \mathrm{C}$. Sumartha, 1990), dan bromelin suhu optimum $50^{\circ} \mathrm{C}$ (Mantell, et al. 1985).
Perbedaan nilai $\mathrm{pH}$ dapat dilihat pada Tabel 4. Dimana semakin tinggi pemberian pasta jahe semakin rendah juga nilai $\mathrm{pH}$ daging ayam kampung.

\section{B. Kualitas Kimia Daging \\ 1. Kadar Air}

Daging ayam kampung yang diberi pasta jahe memiliki rata-rata kadar air yang dapat dilihat pada Tabel 5.

Tabel 5. Rata-rata kadar air daging ayam kampung yang diberi pasta jahe

\begin{tabular}{cccc}
\hline \multirow{2}{*}{ Ulangan } & \multicolumn{3}{c}{ Perlakuan } \\
\cline { 2 - 4 } & $\mathrm{P} 0$ & $\mathrm{P} 1$ & $\mathrm{P} 2$ \\
\hline 1 & 60,02 & 60,46 & 62,63 \\
2 & 62,84 & 61,01 & 60,44 \\
3 & 61,60 & 61,10 & 60,39 \\
\hline Rata-rata & $61,49 \pm 1,41$ & $60,86 \pm 0,35$ & $61,15 \pm 1,28$
\end{tabular}

Ket: Tidak berbeda nyata $(p>0,05)$

Hasil sidik ragam menunjukan perlakuan taraf penambahan pasta jahe pada daging ayam kampung tidak berpengaruh nyata terhadap kadar air $(p>0,05)$. Artinya pemberian pasta jahe pada daging ayam kampung tidak berpengaruh nyata terhadap kadar air daging paha ayam kampung.

Rataan kadar air daging paha ayam kampung yang dihasilkan pada penelitian ini yaitu $60,86 \%$ - 61,49 \%. Hasil penelitian lebih rendah dari pernyataan Nurwantoro dan Mulyani, (2003) yaitu kadar air daging dada ayam kampung yaitu berkisar $75 \%$.
Sedangkan menurut Soeparno, (2009) kadar air daging ayam kampung adalah $68-80 \%$. Menurut Puwastien et al., (2000) menyatakan bahwa kadar air daging dada ayam kampung yaitu $71,2 \%$. Kadar air pada daging dipengaruhi umur, spesies ternak, bangsa dan lokasi otot.

\section{Kadar Protein}

Rata-rata nilai kadar protein daging ayam kampung yang diberi pasta jahe dapat dilihat pada Tabel 6 .

Tabel 6. Rata-rata kadar protein daging ayam kampung yang diberi pasta jahe

\begin{tabular}{cccc}
\hline \multirow{2}{*}{ Ulangan } & \multicolumn{3}{c}{ Perlakuan } \\
\cline { 2 - 4 } & $\mathrm{P} 0$ & $\mathrm{P} 1$ & $\mathrm{P} 2$ \\
\hline 1 & 20,66 & 21,54 & 23,46 \\
2 & 20,75 & 21,83 & 23,67 \\
3 & 20,86 & 21,74 & 23,77 \\
\hline Rata-rata & $20,76 \pm 0,10^{\mathrm{a}}$ & $21,70 \pm 0,15^{\mathrm{b}}$ & $23,63 \pm 0,16^{\mathrm{c}}$
\end{tabular}

Ket: Superskrip yang berbeda menunjukkan perbedaan sangat nyat $(p>0,01)$. 
Kadar protein paling rendah pada perlakuan P0 (kontrol) dan kadar protein paling tinggi pada perlakuan P2 (Pemberian $50 \%$ pasta jahe). Hal ini sebabkan perlakuan P0 Hasil penelitian ini menunjukkan bahwa daging ayam kampung mengalami peningkatan dengan pembaluran jahe gajah. Menurut (Akhadiyah dan Jaya, 2012) pembaluran jahe 1-15\% menunjukkan kadar protein lebih tinggi yaitu 61,15. Penelitian menunjukkan konsentrasi tersebut kerja enzim sudah maksimal dan telah menyebar keseluruh daging ayam serta enzim proteolitik telah bekerja

sebagai katalisator dalam proses keempukan, sedangkan dari hasil penelitian menunjukkan bahwa pembaluran jahe gajah memberikan pengaruh yang nyata dalam kadar protein daging ayam kampung. Hal ini diduga pada pembaluran tersebut kerja enzim proteolitik sangat maksimal, sehingga semakin tinggi tingkat pemberian pasta jahe maka kemampuan enzim proteolitik dalam menghidrolisis protein juga semakin tinggi.

Analisis sidik ragam menunjukkan bahwa penmberian pasta jahe berpengaruh sangat nyata pada taraf $1 \%$ terhadap kadar protein daging ayam kampung.

Uji lanjut BNJ (Beda Nyata Jujur) menunjukan bahwa perlakuan P0 berbeda sangat nyata $(p>0,01)$ terhadap perlakuan $\mathrm{P} 1$ dan P2 dan perlakuan P1 berbeda sangat nyata dengan perlakuan P2. Namun perlakuan P2 merupakan perlakuan yang paling baik yang dapat meningkatkan kadar protein daging ayam kampung yaitu yang ditambahkan $50 \%$ pasta jahe. Hal ini disebabkan karena terjadi peningkatan konsentrasi jahe gajah yang digunakan dalam pembaluran sehingga kadar protein akan daging paha ayam akan semakin tinggi. Hasil penelitian menunjukkan bahwa pemeberian pasta jahe pada daging ayam kampung dapat meningkatkan protein daging.

\section{Kadar Lemak}

Kadar lemak daging ayam kampung hasil penelitian berkisar $12,65 \%$ sampai $17,42 \%$. Selengkapnya rata-rata kadar lemak daging ayam kampung yang diberi pasta jahe dapat dilihat pada Tabel 7.

Tabel 7. Rata-rata kadar lemak daging ayam kampung yang diberi pasta jahe

\begin{tabular}{cccc}
\hline \multirow{2}{*}{ Ulangan } & \multicolumn{3}{c}{ Perlakuan } \\
\cline { 2 - 4 } & $\mathrm{P} 0$ & $\mathrm{P} 1$ & $\mathrm{P} 2$ \\
\hline 1 & 17,30 & 15,61 & 12,90 \\
2 & 17,50 & 15,00 & 12,85 \\
3 & 17,45 & 15,03 & 12,20 \\
\hline Rata-rata & $17,42 \pm 0,10^{\mathrm{a}}$ & $15,21 \pm 0,34^{\mathrm{b}}$ & $12,65 \pm 0,39^{\mathrm{c}}$ \\
\hline
\end{tabular}

Ket: Superskrip yang berbeda menunjukkan perbedaan sangat nyata $(p<0,01)$

Berdasarkan analisis sidik ragam menunjukkan bahwa penambahan pasta jahe berpengaruh sangat nyata $(p>0,01)$ terhadap kadar lemak daging ayam kampung. Hal ini disebabkan karena dengan konsentrasi jahe gajah yang meningkat maka kadar lemak akan semakin menurun dimana diberikan pada daging paha ayam kampung yang diberi pembaluran jahe gajah sebesar 50\%, yaitu sebesar 12,65. Soeparno (2009) menyatakan bahwa, variasi komposisi kimia antara kadar lemak dan protein pada daging saling merefleksikan antara satu dengan lainnya dimana apabila kadar protein rendah maka kadar lemak akan tinggi begitu pula sebaliknya.

Uji lanjut BNJ menunjukkan bahwa penggunaan pasta jahe $50 \%$ berbeda sangat 
nyata pada taraf $1 \%$ terhadap kadar lemak daging ayam kampung. Artinya, penambahan jahe pada tingkat $0 \%, 25 \%$ dan $50 \%$ dapat menurunkan nilai kadar lemak dalam daging ayam kampung. Hal ini disebabkan karena enzim lipase yang terdapat dalam jahe bekerja sangat sempurna, mampu memecah lemak dalam daging sehingga lemak menjadi berkurang.

\section{Kualitas Organoleptik}

Uji organoleptik merupakan uji karakteristik pada fisik daging. Uji organoleptik merupakan pengujian berdasarkan tingkat kesukaan (Rais 2011). Rata-rata nilai skor kualitas organoleptik (rasa, aroma, warna, tekstur, dan keempukan) daging ayam kampung yang diberi pasta jahe dapat dilihat pada Tabel 8 .

Tabel 8. Rata-rata nilai skor kualitas organoleptik

\begin{tabular}{cccc}
\hline \multirow{2}{*}{ Peubah } & \multicolumn{3}{c}{ Perlakuan } \\
\cline { 2 - 4 } & $\mathrm{P} 0$ & $\mathrm{P} 1$ & $\mathrm{P} 2$ \\
\hline Rasa & $3,2 \pm 0,42$ & $2,9 \pm 0,57$ & $3,2 \pm 0,79$ \\
Aroma & $3,4 \pm 0,84$ & $3,1 \pm 0,57$ & $3,2 \pm 0,63$ \\
Warna & $3,1 \pm 0,57$ & $3 \pm 0,67$ & $3,2 \pm 0,63$ \\
Tekstur & $2,7 \pm 0,67$ & $2,5 \pm 0,71$ & $2,6 \pm 0,52$ \\
Keempukan & $3,9 \pm 0,57$ & $3,1 \pm 0,88$ & $3,1 \pm 1,20$ \\
\hline
\end{tabular}

Ket: Tidak berbeda nyata $(\mathrm{P}>0,05)$

\section{Rasa}

Pengaruh penambahan pasta jahe pada daging ayam kampung terhadap rasa daging dengan nilai rata-rata dapat dilihat pada (Tabel 8). Berdasarkan hasil analisis sisik ragam bahwa penambahan pasta jahe pada daging ayam kampung tidak berpengaruh nyata $(p>0,05)$. Hal ini menunjukkan tidak ada perbedaan rasa daging ayam dari perlakuan P0 sampai P2. Rasa daging dari perlakuan P0 sampai P2 memperoleh rataan skor 3 yang menunjukkan rasa daging ayam kampung cukup disukai oleh konsumen. Artinya rasa daging penambahan pasta jahe dari $25 \%$ sampai $50 \%$ disukai oleh konsumen atau dalam kategori normal.

Rasa merupakan komponen sensoris yang sangat mendominasi penerimaan konsumen terhadap produk pangan. Respon rasa diterima oleh sensoris pada lidah karena adanya partikel yang terlarut dalam air maupun dalam minyak, serta kelarutan protein terutama protein binding. Menurut Kartika (1988) rasa suatu bahan makanan merupakan hasil kerja sama indera, seperti indera penglihatan, pembauan, pendengaran dan perabaan.

Uji rasa dipengaruhi oleh hasil uji yang lain (aroma, tekstur dan keempukan) sesuai dengan pendapat Forrest, et al., (1975) cita rasa adalah rangsangan syaraf yang dihasilkan oleh bahan yang dimasukkan kedalam mulut, dirasakan terutama oleh syaraf rasa dan bau serta rasa oleh reseptor rasa sakit, sentuhan serta suhu dimulut.

\section{Aroma}

Rata-rata aroma daging ayam dapat dilihat pada (Tabel 8). Hasil analisis sidik ragam menunjukan bahwa tingkat penambahan pasta jahe tidak berpengaruh nyata $(p>0,05)$ terhadap aroma daging ayam kampung. Aroma daging perlakuan P0, P1, dan P3 memperoleh rataan skor 3 yang menunjukkan aroma daging ayam kampung cukup disukai oleh konsumen.

Aroma daging ayam kampung dipengaruhi oleh senyawa volatil dan uap air terlepas selama pemasakan. Reaksi maillard menghasilkan aldehid dari reaksi asam amino bebas dengan gula pereduksi, degradasi lemak (oksidasi dan hidrolisis) 
akan menghasilkan aldehid, lakton, keton, alkohol dan ester (Fellows, 2000). Penambahan pasta jahe pada daging ayam kampung masih dalam kisaran aroma normal daging ayam kampung rataan skor 3 dan belum menunjukkan perubahan aroma. Perubahan aroma terjadi ketika aroma daging ayam yang spesifik mengalami perubahan dengan adanya perlakuan penambahan pasta jahe. Aroma daging ayam kampung penambahan pasta jahe memperoleh rataan skor 3, termasuk dalam kategori cukup suka atau dikategorikan normal.

\section{Warna}

Analisis sidik ragam menunjukkan pembahan pasta jahe pada daging ayam kampung tidak berpengaruh nyata $(p>0,05)$ terhadap warna daging ayam kampung. Rata-rata nilai warna daging ayam kampung dapat dilihat pada (Tabel 8). Pada Tabel 8 dapat dilihat rata-rata nilai semua perlakuan yaitu skala 3, hal ini menujukkan warna daging semua perlakuan berwarna merah. Menurut Taylor (1984), pigmen yang memberikan warna pada daging adalah struktur hem. Hem ini berkombinasi dengan protein membentuk hemoglobin dan mioglobin. Munculnya warna merah cerah pada daging disebabkan oleh adanya ikatan oksigen pada atom besi (Fe2+) pada struktur molekul mioglobin. Kuantitas mioglobin bervariasi diantar jenis ternak, umur, jenis kelamin, otot, dan aktivitas fisik, yang akan mempengaruhi variasi warna daging (Lawrie, 2003).

\section{Tekstur}

Rata-rata tekstur daging ayam kampung yaitu P0 (Kontrol) dengan nilai tekstur 2,7 dan P1 (25\% Pasta jahe) dengan nilai tekstur 2,5 serta P2 (50\% Pasta jahe) dengan nilai tekstur 2,6. Rata-rata nilai tekstur tersebut dapat di lihat pada (Tabel 8). Berdasarkan rata-rata nilai tersebut maka tekstur daging ayam kampung hasil penelitian bertekstur sedang.

Hasil sidik ragam menunjukkan penambahan pasta jahe pada daging ayam kampung tidak berpengaruh nyata $(p>0,05)$ terhadap testur daging ayam kampung. Tekstur daging ayam kampung memperoleh rataan skor 3 yang menunjukkan tekstur daging ayam kampung perlakuan P1 sampai P2 cukup disukai oleh konsumen.

Tekstur dalam produk makanan dipengaruhi oleh kadar air, lemak, protein serta struktur karbohidrat. Koagulasi protein, gelatinisasi kolagen, pelepasan air, dan gelatinisasi pati merupakan faktor-faktor yang mempengaruhi perubahan tekstur. Penambahan pasta jahe pada daging ayam kampung tidak memberikan pengaruh yang nyata terhadap tekstur daging ayam kampung.

\section{Keempukan}

Keempukan daging merupakan atribut mutu yang kompleks. Secara umum, struktur primer yang mempengaruhi keempukan daging adalah integritas myofibril (dikenal dengan efek aktomyosin) dan kontribusi jaringan ikat (kolagen dan elastin). Walaupun kecil, kandungan lemak di dalam daging (marbling) juga memberikan kontribusi pada keempukan daging (Antara, 2011). Rata-rata keempukan daging ayam kampung yaitu $\mathrm{P}_{0}$ (kontrol) dengan nilai tekstur 3,1 dan P1 (25\% pasta jahe) dengan nilai tekstur 3,1 serta P2 (50\% pasta jahe) dengan nilai tekstur 3,9. Ratarata nilai tekstur tersebut dapat di lihat pada (Tabel ). Berdasarkan rata-rata nilai tersebut maka tekstur daging ayam kampung hasil penelitian bertekstur sedang.

Hasil analisis sidik ragam menunjukan bahwa penambahan pasta jahe pada daging ayam kampung tidak berpengaruh nyata $(p>0,05)$ terhadap keempukan daging ayam kampung. Artinya, penambahan pasta jahe pada tingkat $0 \%$, 
$25 \%$ dan $50 \%$ tidak berpengaruh nyata terhadap keempukan daging ayam kampung.

KESIMPULAN DAN SARAN

\section{A. Kesimpulan}

Berdasarkan hasil dan pembahasan dapat disimpulkan sebagai berikut:

1. Pemberian pasta jahe pada daging ayam kampung berpengaruh sangat nyata terhadap penurunan susut masak daging ayam kampung dimana perlakuan terbaik adalah pemberian pasta jahe sebanyak $50 \%$.

2. Pemberian pasta jahe pada daging ayam kampung berpengaruh nyata terhadap peningkatan kadar protein yaitu perlakuan terbaik $50 \%$ dan penurunan kadar lemak yaitu perlakuan terbaik $50 \%$ dan $\mathrm{pH}$ daging ayam kampung yaitu $\mathrm{pH}$ yang normal pada perlakuan terbaik adalah pemberian pasta jahe sebanyak 50\%).

3. Pemberian pasta jahe pada daging ayam kampung tidak berpengaruh nyata terhadap kadar air dan kualitas organoleptik daging ayam kampung.

\section{B. Saran}

Perlu untuk meneliti lebih lanjut pengaruh pasta jahe dengan lama pembaluran dan cara pemasakan yang berbeda terhadap kualitas daging yang cenderung alot.

\section{DAFTAR PUSTAKA}

AOAC The Association of Official Analytical Chemists. 1984. Official Method of Analysis. $12^{\text {th }}$ Ed. Association of Official Analytical Chemist. Washington, DC.

Astawan. 2006. Manfaat Daging. (Online). (http://gizi.net/. Diakses tanggal 21 Februari 2012).
Adnan, M., 1984. Kimia dan teknologi pengolahan susu. Gadjah Mada University Press, Yogyakarta.

Badan Standarisasi Nasional. 2008. Mutu Karkas dan Daging Sapi. SNI 39322008. ICS 67.120.10. Hal: 14-15.

Bambang, P. dan Nesia D. 1992. Ekonomi Teknik , Proyek Peningkatan Perguruan Tinggi Institut Pertanian Bogor, Bogor.

Buckle, K.A., R.A. Edwards, G.H. Fleet, dan W. Wooton. 2007. Ilmu Pangan. Penerjemah: Hari Purnomo dan Adono. International Development Program of Australian Universities and Colleges, UI Press. Jakarta.

Ditjennak. 2006. Statistik Peternakan Indonesia. Direktorat Jenderal Peternakan. Departeman Pertanian Republik Indonesia, Jakarta.

Daryono, E.D. 2010. Pengaruh Jenis Jahe dan Ratio Bahan Terhadap Ekstraksi Oleoresin dari Jahe. Prosiding Seminar Nasional Teknik Kimia "Soebardjon Brotohardjono VII" Teknik Kimia VPN Veteran Surabaya.

Hafid, H. dan Hasnudi. 2000. Persentase karkas ayam broiler yang diberi pakan komplit butiran. Jurnal Penelitian Kultura. Edisi April 2000. Vol. 3 Hal 11-14. Fakultas Pertanian Universitas Sumatra Utara. Medan.

Hafid, H dan Syam, A. 2009. Kualitas Organoleptik Daging Kambing Lokal dan Lama Pelayuan dan Cara Pemasakan yang Berbeda. Laporan Penelitian Dosen Muda. Lembaga 
Penelitian, Universitas halu oleo, Kendari.

Hafid, H. 2013. Materi Kuliah Ilmu Tekhnologi Daging. Jurusan Peternakan Fakultas Peternakan Univ. Halu Oleo, Kendari.

Hanafiah, K.A. 2011. Rancangan Percobaan: Teori dan Aplikasi, Edisi ke-3. PT. Rajawali Pers. Jakarta.

Hehanussa, S.C.H., S. Fredriksz dan L. Jois. 2010. Pengaruh Penggunaan Ekstrak Batang (Hati) Nenas Terhadap Kualitas Organoleptik Daging Ayam Kampung. Jurnal Agroforestry Vol. V No. 3. Bogor.

Hamiudin, (2007). Khasiat Jahe Olahan. PT. Kanisius. Yogyakarta.

Judge, M.D., E.D. Aberle, J.C., Forrest. H.B., Hendrick dan R.A., Merkel. 1989. Principles of Meat Science. $2^{\text {nd }}$ Ed. Kendall, Hunt Publishing Co. Dubuque. Lowa.

Kikuzaki, H. dan N. Nakatani. 1993. Antioxidant effects of some ginger constituents. Journal Food Science, Vol. 58, 1407.

Komariah, I.I. Arief dan Y. Wiguna, 2004. Kualitas Fisik Dan Mikroba Daging Sapi Yang Ditambah Jahe (Zingiber Officinale Roscoe) Pada Konsentrasi Dan Lama Penyimpanan Yang Berbeda. Media Peternakan, hlm. 4654 Vol. 27 N0. 2.

Koswara, S. 1995. Jahe dan Hasil Olahannya. Pustaka Sinar Harapan. Jakarta.
Lawrie, R.A. 2003. Ilmu Daging. Penerjemah: Aminuddin Parakkasi dan Y. Amwila. Universitas Indonesia Press. Jakarta.

Lee, Y.B., D.J. Sehnert, dan C.R. Ashmore. 1992. Tenderization of meat with ginger rhizome protease. J. Food Sci. 51: 1558-1559.

Muchtadi, T.R. dan Sugiyono. 1992. Ilmu Pengetahuan Bahan Pangan. Departemen Pendidikan dan Kebudayaan. Direktorat Jenderal Pendidikan Tinggi. Pusat Antar Universitas, Institut Pertanian Bogor. Bogor.

Mantell. S.H., Matthew, J.A. and Mc Kee, R.A. 1985. Principles of Plant Biotechnologi; An/ Introduction To Genetic Engineering In Plants, Blackweet Scien Publication : London, P. 120.

Nursal, S. Wulandari dan W.S. Juwita. 2006. Bioaktifasi ekstrak jahe (zingiber officinale roxc.) dalam menghambat pertumbuhan koloni bakteri escherichia coli dan bacillus subtilis. Jurnal Biogenesis, Vol. 2(2): 64-66.

Nurwantoro dan S. Mulyani. 2003. Buku Ajar, Dasar Teknologi Hasil Ternak. Fakultas Peternakan Universitas Diponegoro. Semarang.

Paimin, F.B. 1999. Budidaya, Pengolahan, Perdagangan Jahe. Penebar Swadaya. Jakarta.

Rajalakshmi, D. dan S. Narasimhan. 1996. Sources and Methods of Evaluation. Di dalam : DL Madhavi, SS Deshpande and DK Salunkhe, editor. Food Antioxidants. New York : Marcel Dekker. 
Rais H., 2011. Uji organoleptik daging sapi. Departemen Ilmu Produksi dan Teknologi Peternakan. Fakultas Peternakan. Institut Pertanian Bogor. Bogor.

Rismunandar. 1988. Rempah-Rempah Komoditi Ekspor Indonesia. Sinar Baru. Bandung.

Soeparno. 2009. Ilmu dan Teknologi Daging. Cetakan ke lima. Gadjah Mada University Press. Yogyakarta.

Sartika, T. Dan B. Gunawan. 2007. Karakteristik sifat-sifat produktivitas ayam kampung betina fase produksi pada populasi dasar seleksi. Pros. Seminar Nasional Teknologi Peternakan dan Veteriner. Bogor, 21 - 22 Agustus 2007. Puslitibang Peternakan. Bogor. hlm. 576 - 582

Sartika, T dan S. Iskandar. 2007. Mengenal Plasma Nutfah Ayam Indonesia dan Pemanfaatannya. Balai Penelitian Ternak, Puslitbang Peternakan, Bogor. 